\title{
BRITISH MUSEUM NATURAL RADIOCARBON MEASUREMENTS XVII
}

\section{RICHARD BURLEIGH, JANET AMBERS, and KEITH MATTHEWS}

Research Laboratory, The British Museum,

$$
\text { London WC1B 3DG, England }
$$

The following list consists of dates for archaeologic and geologic samples mostly measured from June 1982 to June 1983. The dates were obtained by liquid scintillation counting of benzene using the laboratory procedures outlined in previous lists (see, eg, BM-VIII, R, 1976, v 18, p 16). Dates are expressed in radiocarbon years relative to $\mathrm{AD} 1950$ based on the Libby half-life for ${ }^{14} \mathrm{C}$ of $5570 \mathrm{yr}$, and are corrected for isotopic fractionation $\left(\delta^{13} \mathrm{C}\right.$ values are relative to $\left.\mathrm{PDB}\right)$. No corrections have been made for natural ${ }^{14} \mathrm{C}$ variations. The modern reference standard is NBS oxalic acid (SRM 4990). Errors quoted with dates are based on counting statistics alone and are equivalent to \pm 1 standard deviation $( \pm 1 \sigma)$. Descriptions, comments, and references to publications are based on information supplied by submitters.

\section{ARCHAEOLOGIC SAMPLES}

\section{Cherchel series}

\section{Algeria}

Samples from Forum site at Cherchel $\left(36^{\circ} 40^{\prime} \mathrm{N}, 1^{\circ} 40^{\prime} \mathrm{W}\right)$ dated to establish chronology for Islamic period of site. Coll 1981 and subm by T W Potter, Dept Prehist and Romano-British Antiquities, British Mus.

\section{BM-2129. Cherchel}

$1080 \pm 130$

Charcoal, ref $408 \mathrm{OX}$, from floor of bldg overlying forum ambulatory.

BM-2130. Cherchel

$$
460 \pm 50
$$

Charcoal, ref $416 \mathrm{PF}$, from floor of bldg overlying forum ambulatory.

BM-2132. Cherchel

Charcoal, ref 409 OY, from Islamic refuse pit.

BM-2133. Cherchel

Charcoal, ref 501, from floor plaster.

\section{BM-2134. Cherchel}

Charcoal, ref 502, from floor plaster.

$$
\begin{array}{r}
\mathbf{6 5} \pm \mathbf{4 0} \\
\delta^{13} C=-23.8 \%
\end{array}
$$

$$
45 \pm 35
$$$$
\delta^{13} \mathrm{C}=-25.0 \%
$$

$$
\begin{array}{r}
\text { Modern } \\
\delta^{13} C=-25.0 \% \text {. }
\end{array}
$$

General Comment (TWP): result for BM-2134, which is stratified below BM-2133, seems anomalous; BM-2130 is later than expected. Other dates 
fit expectations. For other dates from same site see BM-1909, -1910 (R, 1983, v 25, p 39). Full pub will be in Benseddik, N and Potter, T W, Excavations at the Forum site at Cherchel: Archéol Algér Bull (supp vol), $\mathrm{ms}$ in preparation.

\section{British Isles}

\section{Freshwater shell series}

Shell carbonate (id as aragonite by x-ray diffraction) and protein fractions from Unio tumidus Philipsson, id by M P Kerney, Dept Geol, Imperial Coll, London, live-coll from $\mathrm{R}$ Thames at Culham, Oxfordshire, England $\left(51^{\circ} 40^{\prime} \mathrm{N}, 1^{\circ} 15^{\prime} \mathrm{W}\right.$, Natl Grid Ref SU 500950) and Pangbourne, Berkshire, England ( $51^{\circ} 30^{\prime} \mathrm{N}, 1^{\circ} 5^{\prime} \mathrm{W}$, Natl Grid Ref SU 630760). Coll 1968 and 1923 by J Collins and A J Piele (specimens from British Mus (Nat Hist) colln), respectively. Shell carbonate (aragonite) and protein from Margaritifera auricularia (Spengler), id by S Tillier, Mus Natl Hist Nat, Paris, live-coll from R Saône, France (ca $47^{\circ} \mathrm{N}$, 5 ${ }^{\circ} \mathrm{E}$ ). Coll 1969. Measured for comparison with results for shells of fossil $M$ auricularia from R Thames (BM-1798, -1800: R, 1982, v 24, p 269; Preece et al, in press), to help estimate contribution by dead carbon to dates obtained for older shells.

\section{BM-1801. Carbonate}

$125 \pm 5 \%$ modern $\delta^{13} \mathrm{C}=-10.9 \%$

Unio tumidus from $\mathrm{R}$ Thames at Culham, Oxfordshire (pair of united valves).

\section{BM-1802. Protein}

$178 \pm 5 \%$ modern $\delta^{13} \mathrm{C}=-31.0 \%$ above).

Unio tumidus from $\mathrm{R}$ Thames at Culham (same shell as BM-1801,

\section{BM-2072. Carbonate}

$1525 \pm 30$

$\delta^{13} \mathrm{C}=-9.9 \%$

Unio tumidus from $\mathrm{R}$ Thames at Pangbourne, Berkshire, (3 pairs of united valves).

BM-2073. Protein

$750 \pm 180$ $\delta^{13} \mathrm{C}=-30.6 \%$ 。

Unio tumidus from $\mathbf{R}$ Thames at Pangbourne (same shells as BM2072, above).

\section{BM-2135. Carbonate}

$1480 \pm 50$

Margaritifera auricularia from $\mathrm{R}$ Saône, France (1 valve of united pair).

BM-2136. Protein

$730 \pm 180$

$\delta^{13} \mathrm{C}=-28.5 \%$ above).

Margaritifera auricularia from R Saône (same shell as BM-2135, General Comment (RB): dead carbon contribution cannot be estimated 
from respective measurements of Unio tumidus coll 1968 (BM-1801, -1802) because of bomb carbon effect, and results for shells of this sp coll 1923 (BM-2072, -2073) are inexplicably old, as are those for Margaritifera auricularia recorded as coll 1969 (BM-2135, -2136). Absence of bomb carbon from protein fraction of this shell (BM-2136) indicates that it was not livecoll specimen. Further, definitely live-coll, shells of this sp, of known prebomb age, must be analyzed to resolve this and help provide appropriate dead carbon blanks for measurements of fossil shells of this sp (Preece et al, in press).

\section{Northampton series}

Animal bone (collagen) and wood from stratified sequence of deposits exposed by gravel extraction at Earl's Barton, near Northampton, Northamptonshire, England $\left(52^{\circ} 15^{\prime} \mathrm{N}, 0^{\circ} 55^{\prime} \mathrm{W}\right.$, Natl Grid Ref SP 870625). Coll 1982 and subm by A Currant and C B Stringer, Dept Palaeontol, British Mus (Nat Hist).

\section{BM-2026. Northampton}

$\mathbf{3 4 0 0} \pm \mathbf{5 0}$

Mandible of Bos primigenius from undisturbed peat layer underlying modern soil.

\section{BM-2027. Northampton}

$5230 \pm 45$

Wood (cellulose fraction) from base of peat underlying modern soil and overlying Devensian fluvio-glacial gravels.

\section{BM-2074. Northampton}

$\mathbf{2 3 , 8 8 0} \pm \mathbf{7 7 0}$ (Coelondonta antiquitatis) from Devensian gravels underlying peat and modern soil.

\section{BM-2074C. Northampton}

$25,500 \pm 650$

$\delta^{13} C=-21.0 \%$

Repeat measurement of BM-2074, above, using fresh sample of collagen (total amino acids) separated at Oxford Radiocarbon Accelerator Lab (R Gillespie, pers commun).

General Comment (RB, CA, \& CBS): BM-2026, -2074 add usefully to series of dates for Late Pleistocene/Early Holocene mammalian extinctions ( $R$, 1982, v 24, p 236-238, 262-264). Fragmentary human parietal and postcranial bones from silt lens within gravel are of modern type and though not directly dated probably relate to later prehistoric/early historic activity on site.

\section{Brixworth series}

Samples from All Saints Church, Brixworth, Northamptonshire, England $\left(52^{\circ} 20^{\prime} \mathrm{N}, 0^{\circ} 55^{\prime} \mathrm{W}\right.$, Natl Grid Ref SP 745708). Coll 1982 and subm by $\mathrm{D}$ Parsons, Univ Leicester. 
BM-2047. Brixworth

Collagen from human bone, ref 3002 , from burial in NE angle of foundations.

\section{BM-2047A. Brixworth}

$\mathbf{7 4 0} \pm \mathbf{7 0}$

Repeat measurement of BM-2047, above.

\section{BM-2048. Brixworth}

$$
\delta^{13} \mathrm{C}=-19.7 \%
$$

Collagen from human bone, ref 3005 , from burial in cist of rough hewn slabs cut into mortar floor.

\section{BM-2154. Brixworth}

$$
900 \pm 150
$$

Charcoal, ref 900, from ditch primary fill.

$$
\delta^{13} C=-24.7 \%
$$

\section{BM-2155. Brixworth}

Charcoal, ref $364 \mathrm{C}$.

General Comment (JA): dates relate also to experimental work on dating of carbonate materials (mortars) which will be pub elsewhere.

\section{Harrow Hill series}

Charcoal and red deer antler from Neolithic flint mine shafts at Harrow Hill, near Worthing, Sussex, England ( $50^{\circ} 50^{\prime} \mathrm{N}, 0^{\circ} 30^{\prime} \mathrm{W}$, Natl Grid Ref TQ 080100). Coll 1982 and subm by G de G Sieveking, Dept Prehist and Romano-British Antiquities, British Mus.

BM-2071. Harrow Hill

$$
\begin{array}{r}
4670 \pm 60 \\
\delta^{15} C=-26.7 \%
\end{array}
$$

Charcoal, ref HH19 (Corylus sp, id by Rowena Gale, Royal Botanic Gardens, Kew), in Shaft 13c, $5 \mathrm{~cm}$ above base of shaft.

\section{BM-2075. Harrow Hill}

$$
4790 \pm 50
$$

$$
\delta^{13} \mathrm{C}=-26.4 \% \text { o }
$$

Charcoal, ref HH19; repeat measurement of BM-2071, above, using fresh material.

\section{BM-2097. Harrow Hill}

$4910 \pm 110$

Charcoal, ref HH43, from fill of Shaft 13a.

$$
\delta^{13} C=-25.2 \% \text { o }
$$

\section{BM-2098. Harrow Hill}

$$
5120 \pm 120
$$

Charcoal, ref HH28, from fill of Shaft 13g.

$$
\delta^{13} C=-25.7 \%
$$

\section{BM-2099. Harrow Hill}

$$
4820 \pm 70
$$$$
\delta^{13} \mathrm{C}=-23.1 \% \text { o }
$$

Red deer antler (collagen), ref HH27, $5 \mathrm{~cm}$ above floor, on crawling floor to Gallery 13 I.

\section{BM-2124. Harrow Hill}

$$
4800 \pm 170
$$

$$
\delta^{1.2} \mathrm{C}=-24.9 \%
$$

Charcoal, ref HH84, from fill of Shaft 13c, 1.5m above base of shaft, assoc with Mollusca (Kerney, in press). 
General Comment (GdeGS): dates for these samples from freshly excavated mine confirm previous earlier dating (ca 2700-3000 bc) for S Downs group of flint mines ( $\mathrm{R}, 1969$, v 11, p 285-286) relative to Grime's Graves (ca $2000 \mathrm{bc}$ ) and other groups (ca $2500 \mathrm{bc}$ ).

\section{BM-2088. Witton}

$$
\begin{array}{r}
3090 \pm 60 \\
\delta^{13} C=-25.0 \% \text { o }
\end{array}
$$

Charcoal sample from pit fill at Witton, Norfolk, England $\left(52^{\circ} 50^{\prime} \mathrm{N}\right.$, $1^{\circ} 30^{\prime} \mathrm{E}$, Natl Grid Ref TG 334319) assoc with late Beaker and plain wares (Lawson, in press). Coll 1981 by J Owles and subm by A J Lawson, Norfolk Archaeol Unit. Fractionation correction estimated. Comment (AJL): sample was from apparently sealed context, although some animal disturbance was noted; no other contemporary activity has been identified in area. Assoc of plain wares and late Beaker sherds is not surprising but date is later than expected for both types. Date is comparable with that for Billingborough Fen (BM-1410, $3150 \pm 60$ : R, 1981, v 23, p 15) which has well-defined Bucket Urn ceramic component which might be considered to be stylistically later than Witton plain wares.

\section{BM-2091. Haddenham}

$1760 \pm 70$

Wood bark, ref 063, id as probably oak by Maisie Taylor, from base of outer ditch of presumed Neolithic causewayed enclosure at Wright Farms, Earith Row, Haddenham, Cambridgeshire, England $\left(52^{\circ} 25^{\prime} \mathrm{N}\right.$, $0^{\circ} 5^{\prime}$ E, Natl Grid Ref TL 412736). Coll 1981 and subm by I R Hodder, Dept Archaeol, Univ Cambridge and Cambridgeshire Archaeol Comm. Comment (RB): sample appears to be misassoc.

\section{Burghfield Quarry}

Wood, id as oak, ref 40.82, from outer edge of 'logboat' coffin (Ashbee, 1960) under 'yellow silt' floodplain deposit of lower Kennet Valley, discovered during gravel extraction at Burghfield Quarry, Burghfield, near Reading, Berkshire ( $51^{\circ} 25^{\prime} \mathrm{N}, 1^{\circ} 0^{\prime} \mathrm{W}$, Natl Grid Ref SU 705710). Coll 1982 by C L Cram and P Worsley and subm by C L Cram, Reading Mus. Measured to obtain youngest date for tree and terminus ante quem for burial.

BM-2096. Burghfield Quarry

\section{BM-2096A. Burghfield Quarry}

Repeat measurement of BM-2096, above.

$$
\begin{array}{r}
1500 \pm \mathbf{6 0} \\
\delta^{13} C=-23.6 \% 0 \\
\mathbf{1 7 5 0} \pm \mathbf{5 0} \\
\delta^{13} C=-23.6 \% 0
\end{array}
$$

General Comment (RB): result shows burial is later than expected (ca $1500 \mathrm{bc}$ ), but indicates late survival of this burial practice.

\section{BM-2123. Flag Fen}

$2610 \pm 60$

$\delta^{13} C=-23.3 \%$ o

Cellulose extracted from sapwood sample from artificial wooden platform at Flag Fen, near Fengate, Peterborough, England $\left(52^{\circ} 30^{\prime} \mathrm{N}, 0^{\circ} 10^{\prime}\right.$ W, Natl Grid Ref TL 212989). Coll 1982 and subm by F Pryor, Fenland Archaeol Associates. Comment (FP): site is unique in England and was 
possibly used for defense. Date indicates use of site during Ewart Park phase of Late Bronze age, but will have to be used in conjunction with tree-ring studies to give fuller picture of times of use and construction. For dates from nearby site of Fengate see: R, 1975, v 17, p 229; R, 1977, v 19, p 405-406; Pryor (1980).

\section{BM-2137. Devil's Dyke}

$2315 \pm 35$

Charcoal (Prunus sp, Rosaceae, subfamily Pomoideae, Fraxinus sp, Corylus sp, Acer sp) id by Rowena Gale, Royal Botanic Gardens, Kew, from Pit 1, Layer 135-150cm, at Devil's Dyke, near Brighton, Sussex, England $\left(50^{\circ} 50^{\prime} \mathrm{N}, 0^{\circ} 10^{\prime} \mathrm{W}\right.$, Natl Grid Ref TQ 266103). Coll 1982 by Caroline Ellis, M P Kerney and R B G Williams and subm by M P Kerney. Molluscan diagram prepared from sec shows Postglacial biozone d2 (woodland) succeeded by biozones e and f (grassland; Kerney, 1977); charcoal and assoc pottery from near base of zone e. Charcoal-rich layer also corresponds with first appearance of Monacha cartusiana (Müller), molluscan "weed" sp probably introduced to Britain by prehistoric farmers. Comment (MPK \& CE): date is somewhat later than expected for primary forest clearance of adjacent downland, but it should be noted that charcoal horizon lies ca $25 \mathrm{~cm}$ above clearance episode proper (base of molluscan biozone e), and plant taxa represented by charcoals suggest some secondary regeneration. Base of biozone $\mathrm{f}$, which broadly coincides with period of Roman occupation in chalklands of S Britain, lies at convincingly higher level in sec (Ellis, 1983). Though comprising only undiagnostic wall-sherds, hand-made, flint-gritted pottery from charcoal-rich layer is more typical of earlier part of 1st millennium bc (fide Valery Rigby and I A Kinnes, Dept Prehist and Romano-British Antiquity, British Mus).

\section{BM-2150. Devizes Castle}

Cellulose from sample of oak corbel from ceiling in Devizes Castle, now Devizes Mus, Devizes, Wiltshire, England $\left(51^{\circ} 20^{\prime} \mathrm{N}, 2^{\circ} 0^{\prime} \mathrm{W}\right.$, Natl Grid Ref SU 010625) measured to date carving. Sample was heavily contaminated with creosote but this was removed by cellulose extraction. Coll 1983 by Res Lab, British Mus, and subm by G Zarnecki, Univ London. Comment (JA): sample dated composed material from ca 65 annual rings, but date is clearly distinguishable from earliest possible hist date ca $\mathrm{AD} 1150$ and lies close to alternative dating proposed for restoration of castle in ca AD 1500, following Stuiver (1982).

\section{British Middle and Late Devensian sites}

Animal bone (collagen fraction) from stratified cave and rock-shelter sequences (Bramwell, 1973; McBurney, 1959) measured to provide dates for assoc archaeol and environmental record. Extension in collaboration with A J Stuart of program for investigation of Late Pleistocene/Early Holocene mammalian extinctions (R, 1982, v 24, p 236-238, 262-264). 


\section{BM-2102. Bridged Pot}

Fragments of shaft of limb bone of large mammal, id by $\mathrm{K}$ Scott and A J Stuart, from Layer B, angular limestone clasts in red clay/silt matrix, in Bridged Pot, rock shelter at head of Ebbor Gorge, near Wookey Hole, Mendip, Somerset, England $\left(.51^{\circ} 10^{\prime} \mathrm{N}, 2^{\circ} 40^{\prime} \mathrm{W}\right.$, Natl Grid Ref ST 526487). Coll 1958 by C B M McBurney and subm 1982 by A J Stuart, Dept Zool, Univ Cambridge. Comment (AJS): date is later than expected (10,000-11,000 bp) from fauna, which includes reindeer, arctic lemming, and pika.

\section{Picken's Hole series}

Large mammal and reindeer bone, id by $\mathrm{K}$ Scott and A J Stuart, from Picken's Hole cave and rock shelter, Crook Peak, Compton Bishop, Mendip, Somerset, England $\left(51^{\circ} 15^{\prime} \mathrm{N}, 5^{\circ} 55^{\prime} \mathrm{W}\right.$, Natl Grid Ref ST $396550)$. Coll 1963 by E K Tratman and subm 1982 by A J Stuart to verify previous dating $(\mathrm{R}, 1979$, v 21, p 340).

\section{BM-2117. Picken's Hole}

$$
\begin{array}{r}
\mathbf{2 7 , 5 4 0} \pm \mathbf{2 4 4 0} \\
\delta^{13} C=-20.1 \% \text { o }
\end{array}
$$

Fragment of shaft of limb bone of large mammal, ref M30.2/605, Sample C, from Layer 3. Expected date ca 34,000 bp. Comment (AJS): date in broad agreement, though substantially younger than previous date for Layer C, BM-654: $34,265+2600$. Fauna, of Middle Devensian type includes spotted hyena, reindeer, horse, woolly rhinoceros, and mammoth (Stuart \& Scott, ms in preparation). Further samples will be measured.

\section{BM-2118. Picken's Hole}

$$
12,400 \pm 1500
$$

Distal metacarpal of reindeer (Rangifer tarandus) ref M 30.2/57, Sample B, from Layer 5. Expected age ca 40,000 bp. Comment (AJS): date much younger than expected $(>40,000 \mathrm{bp})$. Bone labeled as from Layer 5 , but obtained from trial trench where stratification indistinct; presumably comes from overlying deposit of late Glacial age. Date is acceptable for reindeer. Previous dates for Layer 5, BM-655A, -655B: $26,650+1700$ and $27,000_{-1500}^{+1850}$, are anomalously young. Further samples will be measured.

\section{Ossom's Cave series}

Reindeer and bovid bone, id by K Scott and A J Stuart, from Ossom's Cave, in face of Ossom's Crag, ca $30 \mathrm{~m}$ above valley floor, W side of Manifold Valley, Staffordshire, England $\left(53^{\circ} 5^{\prime} \mathrm{N}, 2^{\circ} 50^{\prime} \mathrm{W}\right.$, Natl Grid Ref SK 096557 ). Coll 1954 by D Bramwell (1973) and subm 1982 by A J Stuart.

BM-2126. Ossom's Cave

$$
\mathbf{2 5 , 3 0 0} \pm \mathbf{1 5 0 0}
$$$$
\delta^{13} C=-20.9 \%
$$

Fragment of shaft of humerus of large bovid, ref Sample C, from 
Layer D, Sq V/VI. Expected age: > 11,000 bp. Comment (AJS): date indicates considerable age difference between Layers D and C.

\section{BM-2127. Ossom's Cave}

$11,930 \pm 310$ $\delta^{13} \mathrm{C}=-22.2 \%$ o

Fragment of shaft of limb bone ( $c f$ reindeer, Rangifer tarandus), ref Sample B, from Layer C, Sq V, red clay layer. Expected age: 10,000-11,000 bp. Comment (AJS): date in broad agreement, but older than, previous date from Layer C, 10,590 \pm 70 (GrN-7400, unpub). Fauna includes reindeer, arctic and Norway lemmings and ptarmigan, in assoc with Upper Palaeolithic industry (Bramwell et al, $\mathrm{ms}$ in preparation). Further samples will be measured.

\section{Choisy-au-Bac series}

\section{France}

Samples from Bronze and Early Iron age site at Choisy-au-Bac, Oise $\left(49^{\circ} 25^{\prime} \mathrm{N}, 2^{\circ} 55^{\prime} \mathrm{E}\right)$. Coll 1978-1981 and subm by J C Blanchet, Centre Natl de la Recherche Scientifique. Comment supplied by S Needham, Dept Prehist and Romano-British Antiquities, British Mus.

BM-2050. Choisy-au-Bac

$$
\begin{array}{r}
\mathbf{2 4 9 0} \pm \mathbf{5 0} \\
\delta^{13} C=-25.0 \% 0
\end{array}
$$

Charcoal, ref $\mathrm{E} 48$, from debris of rampart, assoc with final occupation, Phase IIc.

BM-2051. Choisy-au-Bac

Charcoal, ref W7, from Structure 40, Phase III.

BM-2052. Choisy-au-Bac $\mathbf{2 4 8 0} \pm \mathbf{7 0}$ $\delta^{13} C=-24.8 \%$ o

$2130 \pm 130$

$\delta^{13} C=-24.5 \%$

Charcoal, ref ZB13, from $S$ corner of rampart, corresponding with final debris, Phase IIc.

BM-2053. Choisy-au-Bac

$$
1710 \pm 360
$$

$\delta^{13} C=-24.7 \%$ Phase IIc.

Charcoal, ref $\mathrm{H} 50$, destruction of wooden framework of rampart,

\section{BM-2054. Choisy-au-Bac}

Charcoal, ref C43, rampart debris, Phase IIc.

\section{BM-2055. Choisy-au-Bac}

Wood charcoal, ref E45, from House no. 15, Phase IIc.

\section{BM-2056. Choisy-au-Bac}

Charcoal, ref K49, from House no. 15, Phase IIc.

BM-2057. Choisy-au-Bac

Collagen from bone fragments, ref W4, from Structure 40, Phase III.
$2300 \pm \mathbf{1 1 0}$
$\delta^{13} C=-24.3 \%$ $\mathbf{2 2 3 5} \pm \mathbf{4 0}$
$\delta^{13} C=-21.5 \%$
$2220 \pm 140$

$\delta^{13} \mathrm{C}=-25.0 \%$

$$
2370 \pm 60
$$$$
\delta^{13} \mathrm{C}=-24.6 \%
$$ 


\section{BM-2058. Choisy-au-Bac}

Collagen from bone fragments, ref Q56, House no. 6, Phase Ib.

General Comment (SN): samples refer to sequence of 10 occupation levels separated by alluvial deposits and spanning LBA/EIA transition. Samples come mainly from Phases II and III, which account for 7 of levels (Agache, 1982, p 268-272). Five dates with standard deviations of \pm 70 and less give average date within 5 th century bc, which is later than expected.

\section{Figure of Christ series}

Wood samples (Juglans sp) id by Rowena Gale, Royal Botanic Gardens, Kew, drilled from body and head of near life-sized figure of Christ, of French origin and claimed to date to 12th century AD. Coll 1982 by Research Lab, British Mus and subm by N Stratford, Dept Medieval and Later Antiquities, British Mus.

\section{BM-2100. Figure of Christ}

$490 \pm 100$

Wood drilled from same place in center of back of figure as BM-1977 (see below).

\section{BM-2101. Figure of Christ}

$$
340 \pm 100
$$

Wood drilled from head of figure.

General Comment (RB): for other dates for figure see BM-1977 to -1979 (R, 1983, v 25, p 47-48). Even when max age of $200 \mathrm{yr}$ normally attained by walnut is allowed for, dates indicate real difference in age between detachable arms and body of figure, which is thus a composite piece.

\section{India}

\section{Zawar series}

Samples assoc with zinc mine at Zawar, Udaipur Dist, Rajasthan $\left(24^{\circ} 50^{\prime} \mathrm{N}, 73^{\circ} 50^{\prime} \mathrm{E}\right)$. Coll 1982 by $\mathrm{P}$ Paliwal and $\mathrm{P} \mathrm{T}$ Craddock and subm by P T Craddock, Research Lab, British Mus.

\section{BM-2017. Zawar}

Modern

Charcoal from contents of one retort from many forming long walls across site. Extracted by treatment with hydrofluoric acid.

\section{BM-2065. Zawar}

Modern $\delta^{13} C=-25.0 \%$

Charcoal from similar retort to BM-2017, above, believed to be from Zawar. Extracted by treatment with hydrofluoric acid. Fractionation correction estimated.

\section{BM-2148. Zawar}

$$
\begin{array}{r}
\mathbf{2 1 2 0} \pm \mathbf{6 0} \\
\delta^{1 s} C=-21.8 \%
\end{array}
$$

Wood, ref $\mathrm{LW} / 1982 / 2$, from scaffold in escape route stope inside Zawar Mala mine. 
BM-2149. Zawar

$1920 \pm 50$

Wood, ref LW/1982/1, from launder in escape route inside Zawar Mala mine.

General Comment (PTC): BM-2017, -2065 are inexplicable. Both carbon samples were distributed throughout sintered charge sealed inside clay retorts. By 1820's site is known to have been deserted. Origins of metal production at Zawar are still uncertain. Zinc, with some lead and silver all occur in mines from which timber used for BM-2148, -2149 was taken. Zinc is known to have been smelted from 14th century, but dates suggest zinc and brass production may be much earlier here (Craddock, Gurjar, \& Hegde, 1983).

\section{Indian Ocean}

$$
\mathbf{7 5 0} \pm \mathbf{3 7 0}
$$

BM-2125. Giant tortoise

$\delta^{13} C=-20.9 \%$

Collagen from bony carapace of Geochelone abrupta from colln of Mus Natl Hist Nat, Paris, from Madagascar (Malagasy Republic; ca $22^{\circ} \mathrm{S}$, $45^{\circ} \mathrm{E}$ ), precise loc and date of colln unknown. Subm by E N Arnold, Dept Zool, British Mus (Nat Hist) as part of investigation of hist, distribution and carbon isotope relationships of giant tortoises in Indian Ocean region (R, 1982, v 24, p 245-246). Comment (RB): small size of sample accounts for large error of ${ }^{14} \mathrm{C}$ measurement, but results (date and $\delta^{13} \mathrm{C}$ value) add usefully to others in series (Arnold \& Burleigh, ms in preparation).

\section{Tell Taya series}

Iraq

Samples from site at Tell Taya, near Mosul, N Iraq $\left(36^{\circ} 20^{\prime} \mathrm{N}, 42^{\circ}\right.$ $30^{\prime}$ E). Coll 1973 and subm by J Reade, Dept Western Asiatic Antiquities, British Mus.

BM-2109. Tell Taya

$3370 \pm 45$

Charcoal, ref sample III/3 (batch C 1035), from Level III, old Babylonian period.

BM-2110. Tell Taya

$3650 \pm 40$

Charcoal, ref sample III/8 (batch C 1086), from Level VI, Ur 3 or Late Agade period.

BM-2112. Tell Taya

$3640 \pm 40$

Charcoal, ref sample III/9 (batch C 1107), from Level VIII, Agade period.

$3110 \pm 200$

BM-2113. Tell Taya

$\delta^{1.3} C=-23.9 \%$

Charcoal, ref sample III/16 (batch C 1123), from Level VIII or IX, Agade period.

General Comment (JER): samples are from one area of excavation (Reade 
et $a l, 1973)$ and should all be reliable. Deposit from which BM-2109 derives almost certainly dates from reign of Babylonian king, Hammurapi (1848-1806, 1792-1750, or 1728-1686 BC by three "historic" chronologies most widely used). BM-2110 should be ca 200-350 calendar yr earlier. These two determinations are clearly satisfactory. BM-2112 is stratigraphically earlier than BM-2110 (at least 50 calendar yr earlier) and determination is still satisfactory. BM-2113 must be discounted, perhaps because of very small sample size.

\section{Palestine}

\section{BM-2114. Tell el Ajjul}

$$
\mathbf{8 1 5 0} \pm \mathbf{3 0 0}
$$

$\delta^{13} C=-23.4 \%$ o

Collagen from shaft of left metacarpal (epiphyses not destroyed) of domestic horse (Equus caballus), id by Juliet Clutton-Brock, Dept. Zool, British Mus (Nat Hist), from Burial 1474 at Tell el Ajjūl, Gaza, Palestine $\left(31^{\circ} 30^{\prime} \mathrm{N}, 34^{\circ} 30^{\prime} \mathrm{E}\right)$. Coll 1933-1934 by Sir Flinders Petrie and subm 1982 from British Mus (Nat Hist) colln, to provide direct date for horse skeleton dated from archaeol evidence to Hyksos period, ca 1650-1550 BC (Petrie, 1934, p 15, 16), in support of osteometric studies (Clutton-Brock, in press; Wapnish, in press). Comment (RB): direct dating evidence for early domestic equids in Middle East is sparse due to relative scarcity of well-preserved and well-stratified remains, but on firm archaeol evidence this particular skeleton cannot be earlier than Hyksos period and unexpectedly early date apparently results from incomplete removal of paraffin wax used by Petrie as preservative; hydroxyproline separated from unused epiphyses could be dated by accelerator method (Burleigh, in press).

\section{Padad Kao series}

\section{Papua New Guinea}

Charcoal from ditch intersections in rectangular system of relict agric mounds now under secondary woodland at Padad Kao, $1 \mathrm{~km} \mathrm{SW}$ of Waidoro village, Western Prov $\left(9^{\circ} 10^{\prime} \mathrm{S}, 143^{\circ} 0^{\prime} \mathrm{E}\right)$. Coll 1981 by J R Flenley, Dept Geog, Univ Hull and subm by D R Harris, Inst Archaeol, Univ London.

BM-2093. Padad Kao

Charcoal, ref Pad 1, 20 to $25 \mathrm{~cm}$ depth.

BM-2094. Padad Kao

Charcoal, ref Pad 1, 25 to $30 \mathrm{~cm}$ depth.

\section{BM-2138. Padad Kao}

$$
\text { Modern }
$$
$\delta^{13} C=-27.1 \%$

$$
\begin{array}{r}
\text { Modern } \\
\delta^{13} C=-27.0 \%
\end{array}
$$

Modern $\delta^{13} C=-25.7 \%$ 。

Ciharcoal, ref Pad 6, $45 \mathrm{~cm}$ depth.

General Comment (DRH): recent age of site unexpected; $c f$ date of 780 $\pm 70 \mathrm{bp}$ (Beta Analytic Inc, unpub) for midden under similar site on nearby island of Saibai (Harris \& Laba, 1982; Barham \& Harris, in press). 


\section{Wierzbica series}

\section{Poland}

Charcoal samples from prehistoric flint mine at Zele, Wierzbica, Radom $\left(51^{\circ} 15^{\prime} \mathrm{N}, 2^{\circ} 0^{\prime} \mathrm{E}\right)$ assoc with blade industry. Coll 1981 by $\mathrm{F} \mathrm{M}$ Stepniowski and H Mlynarczyk and subm by J Lech, Inst Hist Material Culture, Polish Acad Sci, Warsaw.

BM-2103. Wierzbica, Zele

Charcoal, ref $1 / 15$, from Cutting II/81, Shaft $11,280 \mathrm{~cm}$ depth.

BM-2104. Wierzbica, Zele

$2460 \pm 140$

Charcoal, ref 2/5, from Cutting II $/ 81$, Shaft $9,200 \mathrm{~cm}$ depth.

\section{BM-2105. Wierzbica, Zele}

$2230 \pm 200$

Charcoal, ref $3 / 76$, from Cutting $I / 80$, Shaft $3,170 \mathrm{~cm}$ depth.

\section{BM-2107. Wierzbica, Zele}

$$
2380 \pm 130
$$

Charcoal, ref 5/10, from Cutting II $/ 81$, Shaft $11,230 \mathrm{~cm}$ depth.

General Comment (RB): dates relate to later occupation of site and not to Early Bronze age (ca 2000-1500 bc) or Neolithic (ca 4200-2000 bc) mining activity, for which there is clear archaeol evidence, or possible terminal Palaeolithic flint exploitation (ca 10,000-8000 bc), for which there is independent archaeol evidence (Lech, 1979; 1981).

\section{Sardinia}

\section{BM-2139. Grotta Filiestru}

$7530 \pm 80$

Collagen from bulked post-cranial bones (ref GFM D61-65) of extinct lagomorph (Prolagus sardus) id by Marsha Levine, Dept Archaeol, Univ Cambridge, from lowest level of fill (Trench D, Layers 7-9) in limestone cave with ca $3 \mathrm{~m}$ undisturbed occupation deposits, Grotta Filiestru, near Bonu Ighinu, commune of Mara, Sassari prov, $30 \mathrm{~km} \mathrm{~S}$ of Sassari $\left(40^{\circ} 30^{\prime}\right.$ N, $8^{\circ} 40^{\prime}$ E). Coll 1980 and subm by D H Trump to provide date for $P$ sardus and for comparison with unpub date for earliest human occupation of cave (Q-3020, 6710 \pm 75 ; Trump, 1983). Comment (RB): result suggests $P$ sardus abandoned Grotta Filiestru well before time of earliest evidence for human occupation, although there is evidence for its later presence (ca $5000 \mathrm{bp}$ ) in less frequented neighboring cave of Su Tintirriolu (Loria \& Trump, 1978). Prolagus survived in Sardinia until historic period (Clutton-Brock, 1981, p 146).

\section{Spain}

\section{BM-1988. Ferrandell Oleza}

$$
3150 \pm 300
$$

$\delta^{13} C=-20.2 \%$

Collagen from teeth and bone sample, from Exploratory Trench 
West, Level II at Beaker settlement site at Ferrandell Oleza, Old Settlement, Valldemosa, Mallorca, Baleares $\left(39^{\circ} 40^{\prime} \mathrm{N}, 2^{\circ} 30^{\prime} \mathrm{E}\right)$, assoc with Beaker pottery, worked flints, and domestic animal remains. Coll 1981 and subm by W H Waldren, Donald Baden-Powell Quaternary Research Centre, Pitt Rivers Mus, Univ Oxford and Dir, Deya Archaeol Mus and Research Centre, Deya de Mallorca. Comment (RB): date is later than expected (ca $2000 \mathrm{bc}$ ).

\section{BM-2001. Olive wood}

$175 \pm \mathbf{3 0}$

Olive wood (Olea europaea) from heartwood of once-large, but gnarled and heavily wind-sculpted living tree on rocky outcrop on cultivation terrace at ca $+300 \mathrm{~m}$, near Deya de Mallorca, Mallorca, Baleares $\left(39^{\circ} 45^{\prime} \mathrm{N}, 2^{\circ} 40^{\prime} \mathrm{E}\right)$. Coll 1981 and subm by R Burleigh. Measured to check age of $>1000 \mathrm{yr}$ frequently claimed for some of trees, and help estimate min age of construction of stone cultivation terraces and irrigation cisterns. Comment (RB): date does not support supposition of great age for individual olive trees based on ancient appearance and large size.

\section{BM-2140. Son Matge}

$$
\begin{array}{r}
\mathbf{2 8 2 0} \pm \mathbf{4 0} \\
\delta^{13} C=-16.0 \% \text { \% }
\end{array}
$$

$63 \mu \mathrm{m}$ fraction of slaked lime sample separated using method of Folk and Valastro (1976) from post-Talayotic quicklime burial in rock shelter at Son Matge, Estret, Valldemosa, Mallorca, Baleares $\left(39^{\circ} 35^{\prime} \mathrm{N}, 2^{\circ} 25^{\prime} \mathrm{E}\right)$. Coll 1981 and subm by W H Waldren. Measured in connection with study of dating of carbonate materials (mortars) which will be pub elsewhere. Comment (JA): cf QL- and Y-series of dates for similar materials in Waldren (1981).

\section{BM-2064. Chinflon}

$\mathbf{2 4 4 0} \pm \mathbf{5 0}$

Cellulose extracted from wood sample id as Erica arborae by Rowena Gale, Royal Botanic Gardens, Kew, from $15 \mathrm{~m}$ depth at junction of modern and earlier mineshafts (Rothenburg \& Blanco Freijeiro, 1980) in mine at Chinflon, Huelva Prov $\left(37^{\circ} 40^{\prime} \mathrm{N}, 6^{\circ} 40^{\prime} \mathrm{W}\right)$. Coll 1981 and subm by P T Craddock, Research Lab, British Mus. Comment (PTC): for other dates from site $c f \mathrm{R}, 1982, \mathrm{v} 24, \mathrm{p}$ 252. Excavations from top of some of ancient mines have produced evidence of Phoenician reworking. Top of this shaft cut underground has not yet been located on surface. Date shows ancient mines are much more extensive than previously thought.

\section{Tell Nebi Mend series}

\section{Syria}

Samples from long sequence of stratified material from multi-period site at Tell Nebi Mend, Qadesh, 30km SW of Homs $\left(34^{\circ} 30^{\prime} \mathrm{N}, 36^{\circ} 30^{\prime} \mathrm{E}\right)$. Dates from 2nd and 1st millennia can be compared with those derived from refs to site in Egyptian, Hittite, and Assyrian texts; 3rd millennium dates should help with Ebla controversy. Coll 1977-1981 and subm by $\mathbf{P}$ J Parr, Inst Archaeol, Univ London. 


\section{BM-2029. Tell Nebi Mend}

Wood charcoal, ref S 109, from VII 100.16.

BM-2030. Tell Nebi Mend

Wood charcoal, ref S 121, from V 105.5.

\section{BM-2032. Tell Nebi Mend}

Wood charcoal, ref S 249, from III 206.24.

\section{BM-2033. Tell Nebi Mend}

Wood charcoal, ref S 251, from III 203.63.

\section{BM-2034. Tell Nebi Mend}

Wood charcoal, ref S 258, from V 105.42.

\section{BM-2035. Tell Nebi Mend}

Wood charcoal, ref S 278, from III 206.15.

BM-2036. Tell Nebi Mend

Charcoal, ref S 280, from VIII 600.29.

BM-2037. Tell Nebi Mend

Charcoal, ref S 281, from III 206.35 .

BM-2038. Tell Nebi Mend

Charcoal, ref S 283, from V 105.7.

\section{BM-2039. Tell Nebi Mend}

Charcoal, ref S 285, from VIII 602.16.

\section{BM-2040. Tell Nebi Mend}

$\mathbf{3 3 1 0} \pm \mathbf{3 5}$

$\delta^{13} C=-22.0 \%$

$$
2700 \pm 40
$$

$\delta^{13} C=-20.4 \%$ o

$$
2925 \pm 45
$$

$\delta^{13} C=-22.4 \%$

$$
\begin{array}{r}
\mathbf{2 2 0 0} \pm \mathbf{5 0} \\
\delta^{1.3} C=-24.7 \% \text { o }
\end{array}
$$

$$
2415 \pm 40
$$

$\delta^{13} C=-22.6 \%$

$$
\begin{array}{r}
\mathbf{3 0 0 0} \pm \mathbf{3 5} \\
\delta^{13} C=-21.6 \%
\end{array}
$$

$$
4220 \pm 120
$$

$\delta^{13} \mathrm{C}=-22.4 \%$

$2720 \pm 230$

$\delta^{13} C=-25.0 \%$

$$
2390 \pm 45
$$

$\delta^{13} \mathrm{C}=-22.2 \%$

$$
\begin{array}{r}
4180 \pm 90 \\
\delta^{13} C=-23.1 \% 0
\end{array}
$$

$$
\begin{array}{r}
3140 \pm \mathbf{6 0} \\
\delta^{13} C=-20.3 \%
\end{array}
$$

General Comment (PP): any comments must be tentative until stratigraphy and assoc material have been fully studied. Ceramic chronology for this part of Syria is at present poorly known; it is hoped excavation will add to refinement of this. BM-2038 is now known to be from mixed provenance and should be disregarded. BM-2033 and -2034 appear to be several centuries too young even when calibrated and are probably contaminated. BM-2029, -2032, $-2035,-2037,-2040$, and possibly BM-2030 fit pottery evidence when calibrated (Clark, 1975). BM-2036 and -2039 fit estimated dates best if uncalibrated. Inconsistencies can only be resolved when further samples have been analyzed and stratigraphy of site correlated with dated hist events and textual material. 


\section{United States}

\section{Indian Fort Road series}

Samples from logs on old ground surface beneath earthen palisade mound assoc with Iroquois village site at Indian Fort Road, near Trumansbury, Tompkins Co, New York $\left(42^{\circ} 30^{\prime} \mathrm{N}, 76^{\circ} 40^{\prime} \mathrm{W}\right)$. Measured to establish 1st absolute dates for late Cayuga Iroquois settlements (Jones \& Jones, 1980). Coll 1980 and subm by K Thomas, Inst Archaeol, Univ London, for D M Jones.

\section{BM-2120. Indian Fort Road}

$\mathbf{8 0} \pm \mathbf{3 5}$

Charcoal, ref 69 (Fagus sp) id by Joan Sheldon, Inst Archaeol, Univ London.

\section{BM-2121. Indian Fort Road}

Charcoal, ref 57 .

\section{BM-2122. Indian Fort Road}

Charcoal, ref 60 (Quercus sp) id by Joan Sheldon.

$$
\begin{array}{r}
200 \pm \mathbf{3 0} \\
\delta^{13} C=-23.5 \% o \\
\mathbf{1 2 5} \pm \mathbf{4 0} \\
\delta^{13} C=-24.3 \% o
\end{array}
$$

General Comment (KT \& DMJ): interpretation of results is complicated by difficulty of calibrating dates of period. BM-2121 seems to fit best with archaeol and documentary evidence from site.

\section{Copal series}

\section{GEOLOGIC SAMPLES}

Copal (resin) of E African origin (ca $7^{\circ} \mathrm{S}, 38^{\circ} \mathrm{E}$; precise locality and date of colln unknown). Subm by P E S Whalley, Dept Entomol, British Mus (Nat Hist), to provide date for large pieces in British Mus (Nat Hist) colln having numerous insect inclusions.

\section{BM-2115. E African copal}

$$
\begin{array}{r}
10 \pm \mathbf{5 0} \\
\delta^{13} C=-26.0 \% \text { o } \\
\mathbf{5 0 \pm 5 0} \\
\delta^{13} C=-21.5 \% \circ
\end{array}
$$

BM-2116. E African copal

General Comment $(\mathrm{RB})$ : insect inclusions in copal ca $<25,000 \mathrm{yr}$ old are of little palaeontol value despite frequent near-perfect 3-dimensional preservation; copal has generally been assumed to be of "Pleistocene" age (ie, not less than ca $1 \mathrm{Myr}$ ), but these results, together with others in series (R, 1982, v 24, p 256), show that entomol study of African and other copal (gum) cannot be undertaken without support of definite (min) date for pieces studied (Burleigh \& Whalley, in press).

\section{REFERENCES}

Agache, R, 1982, Girconscription de Picardie: Gallia Prehistorie, v 25, p 251 -291.

Ashbee, P, 1960, The Bronze age round barrow in Britain: Phoenix House, London, p $86-91$.

Barham, A J and Harris, D R, in press, Relict field systems in the Torres Strait region, in Farrington, I S, ed, British Archaeol Repts, Internatl ser, Oxford, in press.

Bramwell, D, 1973, Archaeology in the Peak District: Moorland Pub Co. 
Burleigh, R, in press, Chronology of some early domestic equids in Egypt and Western Asia, in Uerpmann, H-P and Meadow, $\mathrm{R}$ H, eds, Beih zum Tübinger Atlas des Vorderen Orients: Reihe A, in press.

Burleigh, $\mathbf{R}$ and $W$ halley, $P$, in press, On the relative geological ages of amber and copal: Jour Nat Hist, in press.

Clark, R M, 1975, A calibration curve for radiocarbon dates: Antiquity, v 49, p 251-266.

Clutton-Brock, J, 1981, Domesticated animals from early times: London, British Mus (Nat Hist) and William Heinemann.

- in press, Osteology of the equids from Sumer, in Uerpmann, $\mathrm{H}-\mathrm{P}$ and Meadow, $\mathrm{R}$ H, eds, Beih zum Tübinger Atlas des Vorderen Orients: Reihe A, in press.

Craddock, P T, Gurjar, L K, and Hegde, K T M, 1983, Zinc production in medieval India: World Archaeol, v 15, no. 2, p $211-217$

Ellis, C S, 1983, Dry-valley fills at Asham and the Devil's Dyke, in Mortimore, R N, ed, Internatl flint symposium, 4th: Brighton, England, 10-15 Apr, 1983, Excursion Guide, p 9-23.

Folk, R L and Valastro, S, 1976, Successful technique for the dating of lime mortar by carbon-14: Jour Field Archaeol, v 3, p 203-208.

Harris, D and Laba, B, 1982, The mystery of the Papuan mound-builders: Geog Mag, v 54, p $886-391$.

Jones, D M and Jones, A, 1980, The defences at Indian Fort Road, Tompkins County, New York: Pennsylvania Archaeologist, v 50, p 61-71.

Kerney, M P, 1977, A proposed zonation scheme for Late-glacial and Postglacial deposits using land Mollusca: Jour Archaeol Sci, v 4, p 387-390.

- in press, Mollusca from the Harrow Hill excavations, 1982: in press.

Lawson, A J, in press, The archaeology of Witton, near North Walsham, Norfolk: East Anglian Archaeol, in press.

Lech, J, 1979, Flint mining among the early farming communities of Poland, in Engelen, F H G, ed, Internatl symposium on flint, 3rd Maastricht, Netherlands, 24-27 May, 1979, Proc: Nederlandse Geol Vereniging (Staringia no. 6), p 39-46. 1981, Flint mining among the early farming communities of Central Europe: Przeglad Archeol, v 28, p 5-55.

Loria, R and Trump, D, 1978, Le scoperte a "Sa 'Ucca de Su Tintirriolu" e il neolitico sardo: Monumenti Antichi, ser miscel, v II (2), Accad Naz dei Lincei, Rome.

McBurney, C B M, 1959, Report on the first season's fieldwork on British Upper Palaeolithic cave deposits: Prehist Soc Proc, v 25, p 260-269.

Petrie, Sir Flinders, 1934, Ancient Gaza IV 'Tell el Ajjūl: London, British School of Archaeol in Egypt and Bernard Quaritch.

Precce, R C, Burleigh, R, Kerney, M P, and Jarzembowski, E A, in press, Radiocarbon age determinations of fossil Margaritifera auricularia (Spengler) from the River Thames in west London: Jour Archaeol Sci, in press.

Pryor, F, 1980, Excavations at Fengate, Peterborough, England-3rd report: Northamptonshire Archaeol Soc Mon 1 and Royal Ontario Mus Archaeol Mon 6.

Reade, J E et al, 1973, Tell Taya (1972-73)-summary report: Iraq, v 35, p 155-187.

Rothenberg, B and Blanco Freijeiro, A, 1980, Ancient copper mining and smelting at Chinfor (Huelva, S W Spain), in Craddock, P T (ed), Scientific studies in ancient mining and metallurgy (British Mus Occ Paper 20): London, British Mus, p 41-62.

Stuiver, M, 1982, A high-precision calibration of the AD radiocarbon time scale: Radiocarbon, v 24, p $1-26$.

Trump, D, 1983, La Grotta Filiestru, Mara: Quaderni d Soprintendenza alle Antichità, Sassari.

Waldren, W H, 1981, Radiocarbon determination in the Balearic Islands-an inventory 1962-1981: Oxford, Donald Baden-Powell Quaternary Research Centre.

Wapnish, P, in press, Osteometric study of domestic equid remains from Tell el Ajjül, Palestine, in Uerpmann, H-P, and Meadow, R H, eds, Beih zum Tübinger Atlas des Vorderen Orients: Reihe A, in press. 